\title{
IN VIVO AND IN VITRO ACTIVITY \\ OF 1-AMINOCYCLOPROPANE-1-CARBOXYLIC ACID OXIDASE IN GERMINATING SEEDS OF CHINA ASTER (CALLISTEPHUS CHINENSIS NEES)
}

\author{
Mariusz CHOJNOWSKI*, Anna SKORUPIŃSKA \\ Research Institute of Horticulture \\ Konstytucji 3 Maja 1/3 St., 96-100 Skierniewice, Poland
}

Received: April 2020; Accepted: October 2020

\begin{abstract}
The activity of 1-aminocyclopropane-1-carboxylic acid oxidase (ACO; EC 1.4.3.3) in germinating seeds of Callistephus chinensis was studied. For maximum recovery of ACO activity in vitro, the presence of $10 \%$ (w/v) insoluble polyvinylpolypyrrolidone (PVPP) and 30\% of glycerol in the extraction medium was necessary. The optimum $\mathrm{pH}$ for this activity was 7.0. Ethylene production by whole achenes or enzymatic extract increased due to increasing 1-aminocyclopropane-1-carboxylic acid (ACC) concentrations. Saturation level of ACC for in vivo ACO activity was $10^{-1} \mathrm{M}$ and $\mathrm{V}_{\max }$ was $10.89 \mathrm{~nL} \mathrm{C}_{2} \mathrm{H}_{4} \cdot \mathrm{mg}$ protein ${ }^{-1} \cdot \mathrm{h}^{-1}$. For in vitro ACO activity, the saturation level of ACC was $10^{-3} \mathrm{M}$ and $\mathrm{V}_{\max }$ was $2.299 \mathrm{~nL} \mathrm{C}_{2} \mathrm{H}_{4} \cdot \mathrm{mg}$ protein ${ }^{-1} \cdot \mathrm{h}^{-1}$. Both, in vivo and in vitro ACO activities did not follow Michaelis-Menten kinetics. The Hill coefficients $(h)$ were estimated on the basis of non-linear estimation. Their values were 0.63 for in vivo ACO activity and 1.73 for in vitro ACO activity. The experimental data show that ACO from C. chinensis seeds is an oligomeric enzyme with at least two active sites. During seed germination, in vitro ACO activity was detectable after 12 hours of imbibition, while in vivo ACC conversion to ethylene was observed after $24 \mathrm{~h}$, i.e. - after radicle protrusion. The activity of ACO in C. chinensis seeds is associated with germination sensu stricto, and might be a good marker of this process.
\end{abstract}

Keywords: ACC oxidase, ACO, Callistephus chinensis, germination sensu stricto

\section{INTRODUCTION}

Ethylene has a crucial function in breaking dormancy and stimulating germination of seeds (Kępczyński \& Kępczyńska 1997; Matilla 2000, Corbineau et al. 2014). However, the quantities of endogenous ethylene released from seeds are barely detectable before seed coat rupture by the radicle. The evolution of ethylene and 1-aminocyclopropane1-carboxylic acid (ACC) conversion into ethylene is mainly located in the embryonic axes (Petruzzelli et al. 2000) and can be regulated by positive feedback. Close relationships between ethylene production by germinating seeds of some species and their vigor have been found (Samimy \& Taylor 1983; Fu et al. 1988; Gorecki et al. 1991; Chojnowski et al. 1997,
Siriwitayavan et al. 2003). For some vegetable seeds, measurement of ACC-dependent ethylene production was proposed as a rapid vigor test (Khan 1994). Incubation of seeds in the solutions of ACC, an immediate precursor of ethylene synthesis, significantly increased sensitivity of this test (Khan 1994). Seeds of Callistephus chinensis, differing in vigor due to their position on the mother plants show variability in their ability to convert ACC to ethylene (Grzesik et al. 1997) corresponding to seed germinability.

Since the complete recovery of ethylene forming activity in vitro was described by Ververidis and John (1991), 1-aminocyclopropane-1-carboxylic acid oxidase (ACC oxidase, ACO; EC 1.4.3.3) (Pech et al. 2010) has been isolated and characterized in many plants. 
The essential cofactors necessary for its activity are ascorbate and iron (Bouzayen et al. 1991; Ververidis \& John 1991) as well as $\mathrm{CO}_{2}$ (Smith \& John 1993; Yang \& Dong 1993; Mathooko 1996). ACC-oxidase is a bi-substrate enzyme and oxygen is necessary as a second substrate (McGarvey \& Christoffersen 1992; Bailly et al. 1995; Mirica \& Klinman 2008).

There are many isoforms of ACO described in plant tissues. The biochemical properties, genes encoding ACO as well as the transcriptional, posttranscriptional, and post-translational control of ACO were reviewed by Ruduś et al. (2013) and Houben and Van de Poel (2019). In germinating seeds, ACO was isolated and studied for many species, but it was characterized only for some of them, for example, for chickpea (Muñoz de Rueda et al. 1995), Amaranthus caudatus (Kępczyński et al. 1999), and Stylosanthes humilis (Barros et al. 2013).

The aim of this study on regulating ACO activity in germinating seeds of $C$. chinensis was: (I) to optimize the extraction and incubation methods for measuring $\mathrm{ACO}$ in vitro activity, (II) to study the effects of ACC concentration on in vivo and in vitro activity of ACO, and (III) to evaluate this activity in dry and germinating seeds.

\section{MATERIALS AND METHODS}

\section{Seed germination}

Seeds of $C$. chinensis Nees 'Hölderin' were obtained from PlantiCo Gołębiew (Poland). The seeds were stored in paper bags in a cold room, at a temperature of $5{ }^{\circ} \mathrm{C}$ and at $40 \%$ relative humidity. Seeds (whole achenes) were placed in $60 \mathrm{~mm}$ Petri dishes on one layer of filter paper (Whatman, no. 17) moistened with $3 \mathrm{~mL}$ of distilled water. Petri dishes were tightly closed with Parafilm. Germination was carried out in darkness at $25{ }^{\circ} \mathrm{C}$, i.e. - optimal temperature for this cultivar (Chojnowski 2000). To estimate the enzyme activity, seeds not germinated and germinated for 12, 24, 36 or 48 hours (depending on the experiment) were used.

\section{ACC oxidase extraction}

For extraction of ACC oxidase the whole achenes or seeds without pericarps were frozen at $-70{ }^{\circ} \mathrm{C}$ and ground with a mortar and pestle. The powder was mixed with an extraction medium that consisted of $0.1 \mathrm{M}$ Tricine buffer ( $\mathrm{pH} 6.5,7.0,7.5$ or 8.0), $30 \%(\mathrm{v} / \mathrm{v})$ glycerol, 5 or $10 \%$ insoluble polyvinylpolypyrrolidone (PVPP), $30 \mathrm{mM}$ sodium ascorbate, $0.1 \%(\mathrm{v} / \mathrm{v})$ Triton X-100 and $5 \mathrm{mM}$ dithiothreitol, using $1 \mathrm{~g}$ of seed material and $2 \mathrm{~mL}$ of extraction medium. The mixture was centrifuged for $30 \mathrm{~min}$ at $28,000 \times \mathrm{g}$. The extraction procedure was conducted at $4{ }^{\circ} \mathrm{C}$.

\section{In vitro enzyme assay}

The activity of ACO was estimated according to a modified method of Bailly et al. (1995). In vitro activity of ACO was assayed in a 1-mL reaction mixture including $0.2 \mathrm{~mL}$ of seed crude extract, $0.1 \mathrm{M}$ Tricine buffer, $30 \%$ glycerol, $30 \mathrm{mM}$ sodium ascorbate, $0.1 \mathrm{mM} \mathrm{FeSO}_{4}, 25 \mathrm{mM} \mathrm{NaHCO}$ and ACC at different concentrations. Ethylene produced at $25{ }^{\circ} \mathrm{C}$ in $10 \mathrm{~mL}$ flasks tightly closed with serum caps was collected for various periods (15 minutes to 5 hours depending on the experiment) and measured using gas chromatography.

In vivo enzyme activity and ethylene measurements

The in vivo conversion of ACC to ethylene was assayed in whole achenes. Five replications of 10 seeds each were placed in $10 \mathrm{~mL}$ flasks with $0.5 \mathrm{~mL}$ water or various ACC solutions. After $1 \mathrm{~h}$ pre-incubation at $25^{\circ} \mathrm{C}$, flasks were tightly closed with serum caps for an additional $1 \mathrm{~h}$. For ethylene measurement, $1 \mathrm{~mL}$ headspace gas samples were withdrawn from sealed flasks and injected into a gas chromatograph (HP 5890) equipped with an activated alumina column $(90 \mathrm{~cm}$ long, $0.4 \mathrm{~cm}$ i.d.) and a flame ionization detector. Argon was used as a carrier gas at a flow rate of $20 \mathrm{~mL} \cdot \mathrm{min}^{-1}$, and the oven temperature was $100{ }^{\circ} \mathrm{C}$. Results are expressed as $\mathrm{nL} \mathrm{C}_{2} \mathrm{H}_{4} \cdot \mathrm{mg}$ protein ${ }^{-1} \cdot \mathrm{h}^{-1}$.

\section{Protein determination}

Determination of protein content in germinating seeds was conducted according to the method of Bradford (1976), and BSA was used as a standard.

\section{Statistical analysis}

$\mathrm{K}_{\mathrm{m}}$ defined as the concentration of the substrate, which results in half-maximal velocity for the enzymatic reaction (Copeland 2000), for in vivo and in vitro $\mathrm{ACO}$ activity was calculated by non-linear 
estimation using Levenberg-Marquardt method on the basis of the Henri-Michaelis-Menten equation:

$$
V=\left(V_{\max }[S]\right) /\left(K_{m}+[S]\right) .
$$

The Hill coefficient $(h)$ was calculated by non-linear estimation using Levenberg-Marquardt method on the basis of the Hill equation:

$$
V=\left(V_{\max }[S]^{h}\right) /\left(K^{\prime}+[S]^{h}\right),
$$

where $\mathrm{V}$ is the in vivo or in vitro ethylene production rate at a given concentration of substrate $[\mathrm{S}]$ and $\mathrm{V}_{\max }$ is the ethylene production rate at a saturating substrate concentration, $\mathrm{K}^{\prime}$ is a constant, however, it is not a value that relates to the concentration of substrate, which is necessary to obtain half of maximum velocity of the enzyme activity (Copeland 2000).

All the data were statistically analyzed and presented graphically in Statistica 13 data analysis software system (Dell 2016). Data were presented as a mean of 10 replications (two independent experiments of 5 replications each) \pm standard error (SE) or compared by Duncan's test.

\section{RESULTS AND DISCUSSION}

\section{Extraction and incubation conditions}

The highest in vitro activity of ACC oxidase from C. chinensis seeds was obtained after extraction and incubation at $\mathrm{pH} 6.5$ and 7.0 (Fig. 1). Increasing $\mathrm{pH}$ to 7.5 decreased activity by $30 \%$, and at $\mathrm{pH} 8.0$, it was almost completely inhibited. A higher amount of PVPP (10\% compared with 5\%) in the extraction medium and addition of $\mathrm{NaHCO}_{3}(25 \mathrm{mM})$ to the incubation buffer significantly increased the ACC activity - by $77 \%$ (Table 1). Applied alone, the higher level of PVPP or the addition of $\mathrm{NaHCO}_{3}$ increased the activity of ACC oxidase by $16.4 \%$ and $6.6 \%$, respectively.

The method of Bailly et al. (1995) originally used for sunflower hypocotyl segments, applied to C. chinensis seeds without any modifications, resulted in very limited level of ACO recovery in vitro (data not shown). Optimizing both buffers and $\mathrm{pH}$ levels was necessary. ACO from $C$. chinensis seeds shows the highest activity in Tricine buffer (data not shown). Our work showed that ACO from $C$. chinensis has a $\mathrm{pH}$ optimum close to 7.0, similar to the enzyme obtained from carnation petals (Nijenhuis-de Vries et al. 1994), corn and sunflower (Finlayson et al. 1997), and ACO from seedlings of Pinus nigra (Reynolds \& John 2000). Other reports showed that optimum $\mathrm{pH}$ for in vitro activity of ACO isolated from apple fruit was 7.2 and 7.6 depending on the extraction buffers (Kuai \& Dilley 1992). These differences may result from a buffer applied for extraction and/or incubation procedure. For example, to obtain maximum in vitro activity of ACO from carnation petals, different $\mathrm{pH}$ for extraction and incubation was necessary (Nijenhuis-de Vries et al. 1994; Wawrzyńczak 2002). On the other hand, the most important factor might be the plant and organ dependent characteristics of the enzyme. Gong and McManus (2000) showed that ACC oxidases expressed during the ontogeny of white clover leaves differ in their characteristics, and two different isoforms of the enzyme showed optima of activity at $\mathrm{pH} 7.5$ and 8.5.

Contrary to the method described by Bailly et al. (1995), our results showed that higher levels of PVPP and the addition of $\mathrm{NaHCO}_{3}$ were necessary for optimal ACO activity (Table 1). The higher glycerol concentration (30\% compared with 10\%) improved the recovery of ACC oxidase activity in vitro (data not presented) and such concentration of glycerol was used in further experiments. It had been previously shown (Fernández-Maculet \& Yang 1992) for apple fruits that PVPP greatly improved the recovery of EFE activity from a pellet fraction, and this recovery was enhanced by the presence of ascorbate. In our experiments, increasing the amount of PVPP from 5 to $10 \%$ followed by incubation of the enzyme extract with $25 \mathrm{mM}$ of $\mathrm{NaHCO}_{3}$ gave a significant increase of in vitro ACC oxidase activity (Table 1). The addition of $\mathrm{HCO}_{3}-\mathrm{CO}_{2}$ to the incubation medium also stimulated in vitro ACC oxidase activity in melon fruits (Smith \& John 1993), carnation petals (Nijenhuisde Vries et al. 1994), chickpea embryonic axes (Muñoz de Rueda et al. 1995) and corn seedlings (Finlayson et al. 1997). ACC oxidase, similar to the RuBisCO, is not only activated by $\mathrm{CO}_{2}$, but $\mathrm{CO}_{2}$ is also involved in the enzymatic reaction (Smith \& John 1993; Yang \& Dong 1993). 


\section{Concentration of ACC}

The rate of ethylene production in vivo increased with increasing ACC concentration and the highest rate $\left(10.89 \mathrm{~nL} \mathrm{C}_{2} \mathrm{H}_{4} \cdot \mathrm{mg}\right.$ protein $\left.{ }^{-1} \cdot \mathrm{h}^{-1}\right)$ was detected at $10^{-1} \mathrm{M}$ ACC (Fig. 2). The in vitro activity of ACC oxidase was also dependent on substrate concentration, and the saturation level $\left(2.299 \mathrm{~nL} \mathrm{C}_{2} \mathrm{H}_{4} \cdot \mathrm{mg}\right.$ protein $\left.^{-1} \cdot \mathrm{h}^{-1}\right)$ was reached at a concentration of $10^{-3} \mathrm{M}$ ACC (Fig. 3).

Saturation level of ACC for in vitro ACC oxidase highly depends on the experimental material. The amount of $\operatorname{ACC}\left(10^{-3} \mathrm{M}\right)$, which was necessary to reach saturation level for ACC oxidase from C. chinensis seeds (Fig. 3) was similar to that observed for sunflower hypocotyls (Bailly et al. 1995) and chickpea seeds (Muñoz De Rueda et al. 1995). Bailly et al. (1995) reported that increasing the amount of ACC to $10^{-2} \mathrm{M}$ lowered the activity of ACC oxidase from sunflower hypocotyl segments. For other materials like corn roots and leaves (Finlayson et al. 1997) or leaves of white clover (Gong \& McManus 2000), two to a five-fold higher amounts of ACC were necessary to saturate the enzyme.

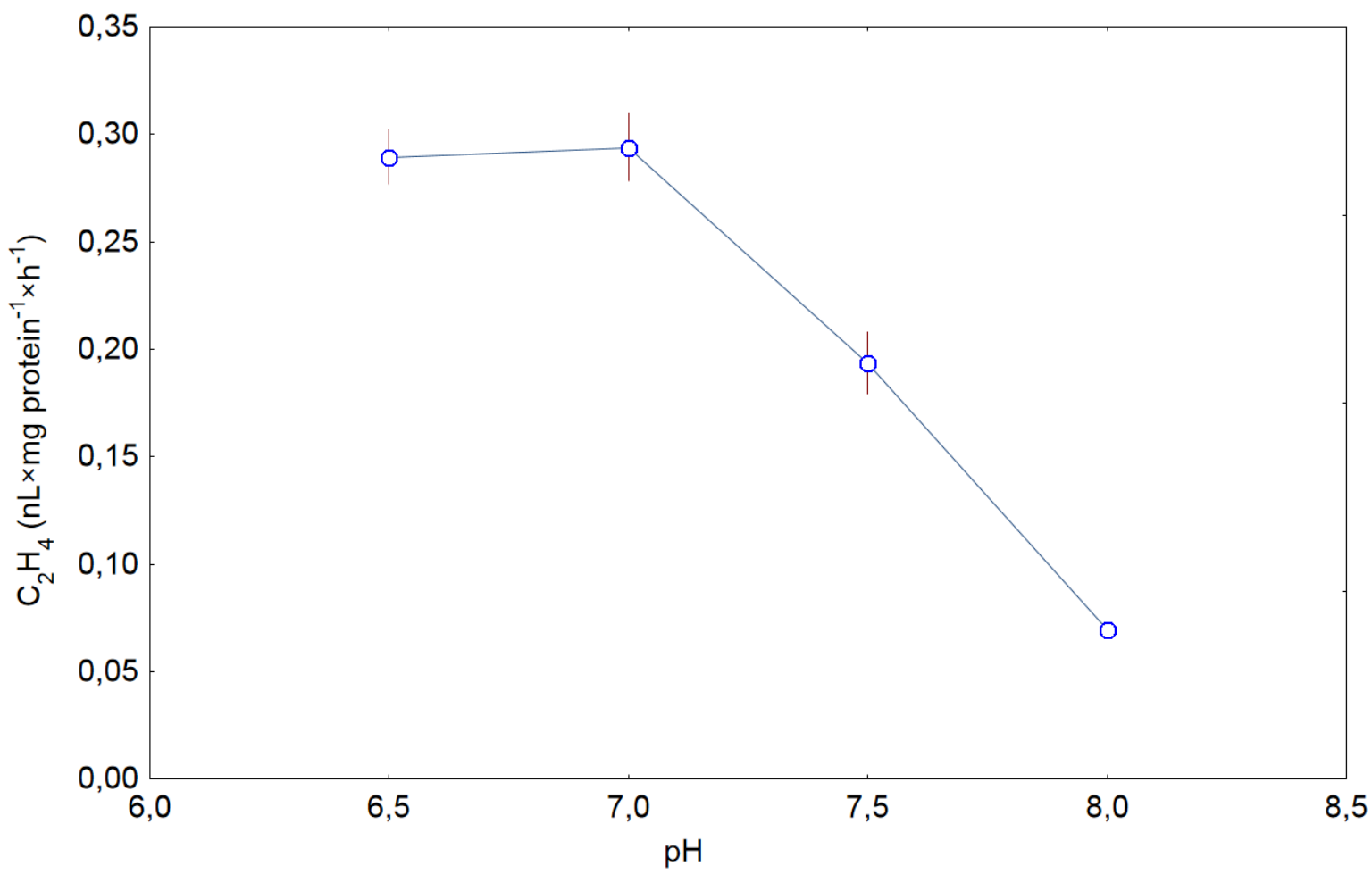

Figure 1. Effect of $\mathrm{pH}$ on in vitro ACC oxidase activity from Callistephus chinensis seeds germinated for $24 \mathrm{~h}$; vertical bars denote $\pm \mathrm{SE}$

Table 1. Effect of PVPP and $\mathrm{NaHCO}_{3}$ on in vitro activity of ACC oxidase from Callistephus chinensis seeds germinated for $48 \mathrm{~h}$. Means followed with the same letter are not significantly different at $\mathrm{p}=0.05$ according to Duncan's test; mean $\pm \mathrm{SE}$

\begin{tabular}{|c|c|c|c|}
\hline PVPP & $\mathrm{NaHCO}_{3}$ & Ethylene $\left(\mathrm{nL} \cdot \mathrm{mg} \operatorname{protein}^{-1} \cdot \mathbf{h}^{-1}\right)$ & Increment (\%) \\
\hline $5 \%$ & - & $1.086 \mathrm{a} \pm 0.042$ & - \\
\hline $5 \%$ & $25 \mathrm{mM}$ & $1.158 \mathrm{a} \pm 0.154$ & 6.6 \\
\hline $10 \%$ & - & $1.246 \mathrm{a} \pm 0.073$ & 16.4 \\
\hline $10 \%$ & $25 \mathrm{mM}$ & $1.925 b \pm 0.217$ & 77.0 \\
\hline
\end{tabular}




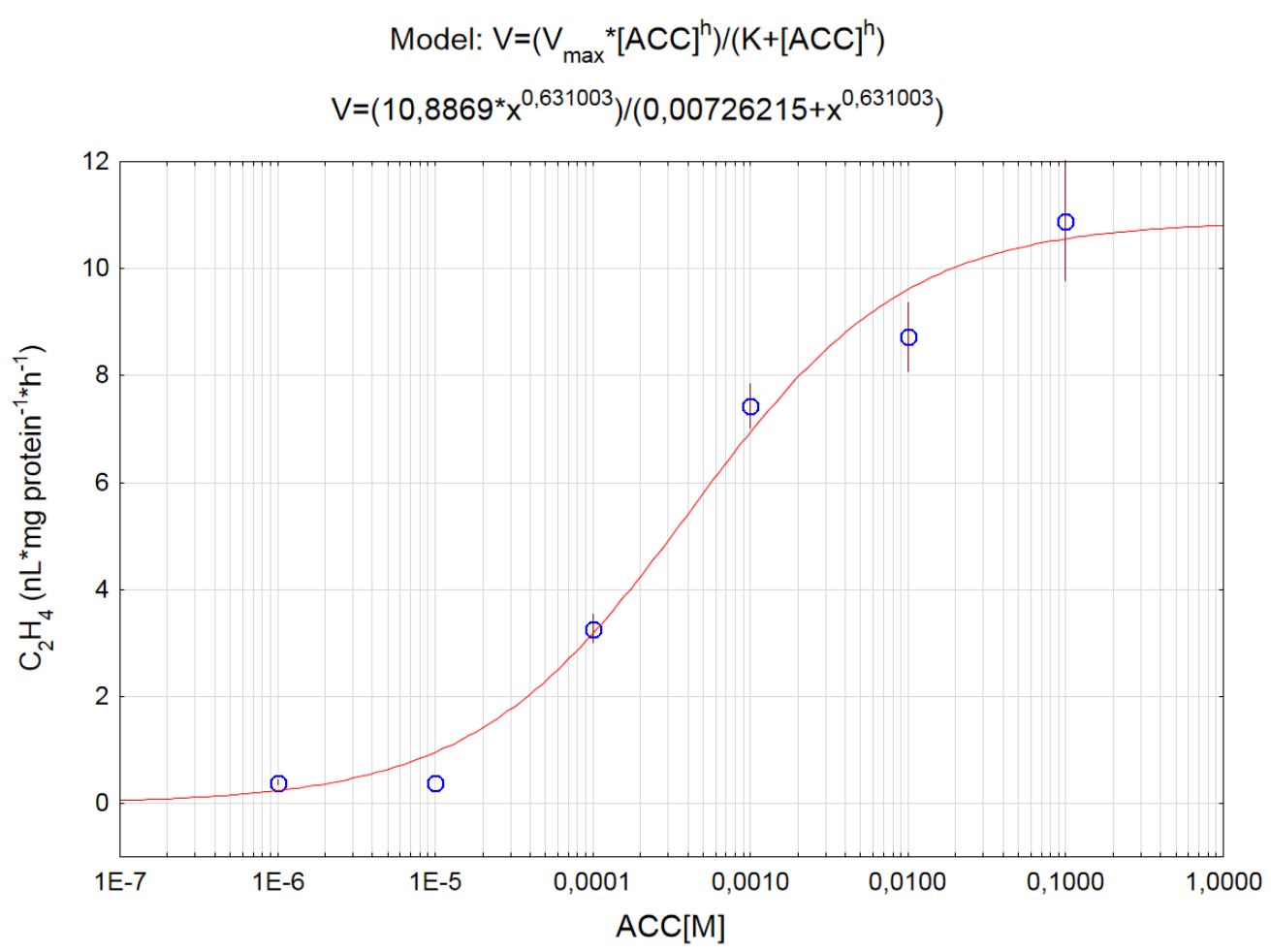

Figure 2. Effect of ACC concentration on in vivo ACC oxidase activity at $25^{\circ} \mathrm{C}$ in Callistephus chinensis seeds germinated for $48 \mathrm{~h}$; vertical bars denote $\pm \mathrm{SE}$

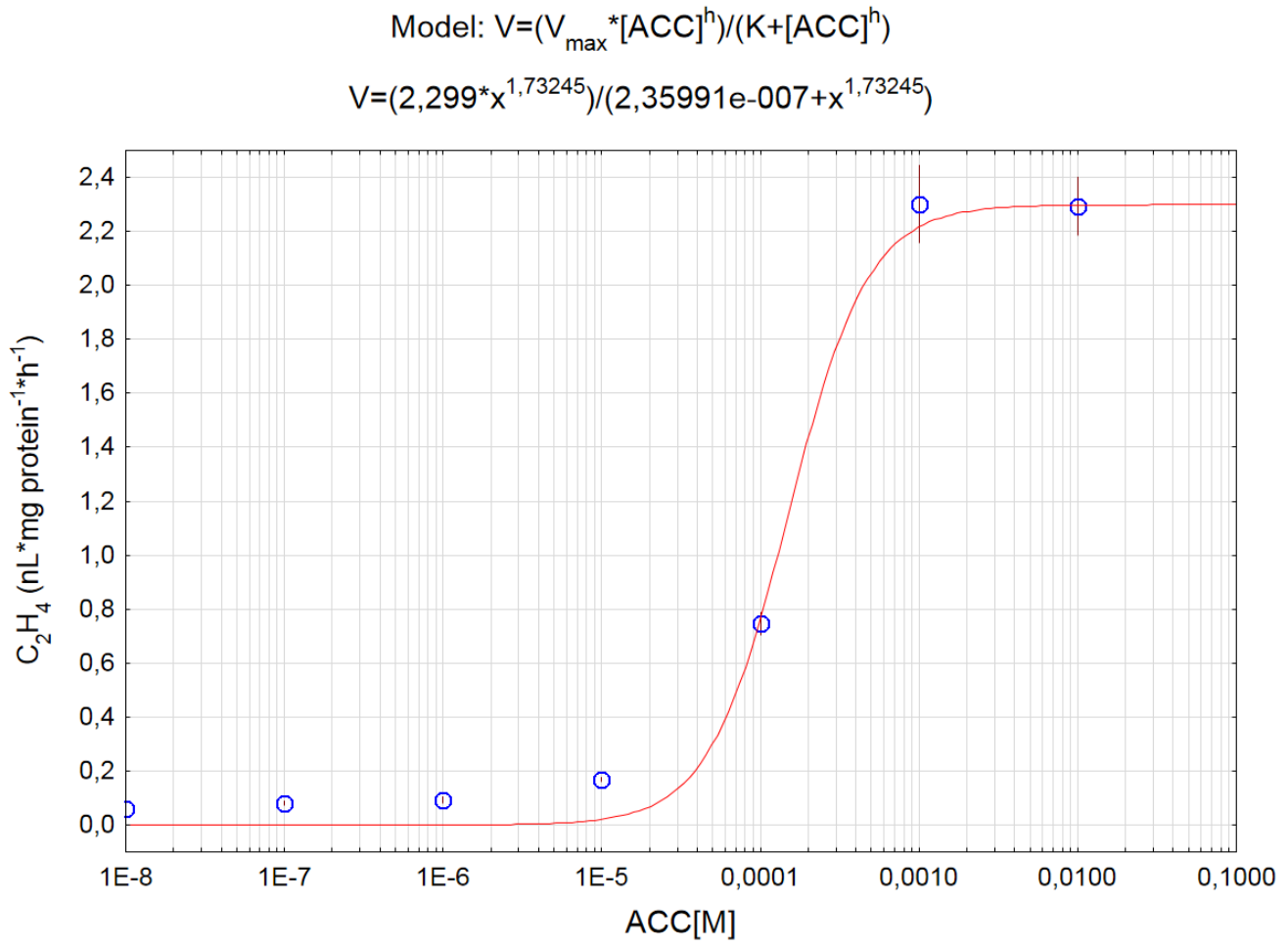

Figure 3. Effect of ACC concentration on in vitro ACC oxidase activity at $25{ }^{\circ} \mathrm{C}$ in Callistephus chinensis seeds germinated for $48 \mathrm{~h}$; vertical bars denote $\pm \mathrm{SE}$ 
The ACO from C. chinensis seeds show relatively low affinity to ACC. The $\mathrm{K}_{\mathrm{m}}$ value calculated on the basis of non-linear estimation was $368 \mu \mathrm{M}$. The in vitro estimated $\mathrm{K}_{\mathrm{m}}$ value $(154 \mu \mathrm{M})$ showed that the affinity of the enzyme for ACC evaluated in vitro, was more than twice higher that for in vivo activity (Table 2). However, non-linear estimation of ACC enzyme kinetics showed that the in vivo and in vitro activities of the ACC oxidase did not follow Michaelis-Menten kinetics. However, many researchers reported Michaelis-Menten kinetics of ACO activity. For example, for ACO from sunflower hypocotyl segments (Bailly et al. 1995) $\mathrm{K}_{\mathrm{m}}$ estimated in vivo was $219 \mu \mathrm{M}$, for ACO from Stylosanthes humilis seeds $-\mathrm{K}_{\mathrm{m}}$ was $230 \mu \mathrm{M}$ (Barros et al. 2013), while for chickpea seeds $\mathrm{K}_{\mathrm{m}}$ was only $120 \mu \mathrm{M}$ (Muñoz de Rueda et al. 1995). For in vitro activity of ACO from $S$. humilis seeds, Barros et al. (2013) reported similar $\mathrm{K}_{\mathrm{m}}$ value to that obtained in our experiment $(156 \mu \mathrm{M})$. On the other hand, $\mathrm{K}_{\mathrm{m}}$ for in vitro activity ACO from sunflower hypocotyl segments (Bailly et al. 1995) and chickpea seeds (Muñoz de Rueda et al. 1995) was as low as $20.6 \mu \mathrm{M}$ and $28 \mu \mathrm{M}$.

ACC oxidase from $C$. chinensis does not show simple hyperbolic saturation curve, but a sigmoidal dependence of ethylene production as a function of ACC concentration (Fig. $2 \& 3$ ). The Hill constants $(h)$ obtained on the basis of the non-linear estimation of Hill equation (Copeland 2000) were 0.63 for in vivo ACC oxidase activity and 1.73 for in vitro ACC oxidase activity (Table 2). The results obtained in our experiments suggest that ACO from $C$. chinensis seeds is an oligomeric enzyme with at least two substrate binding sites. The experimental data showed positive cooperativity between the subunits of ACO analyzed in vitro, while for in vivo ACO activity, this cooperation was negative. Hill coefficient $h=1$ and the oligomeric enzyme activity follows the Michaelis-Menten kinetics only when there is no cooperativity between the active sites of the enzyme (Copeland 2000). Such a lack of cooperativity can explain the Michaelis-Menten kinetics of ACO activity obtained in previous experiments reported by other authors. The results of our experiments are in agreement with the results presented by Zhang et al. (2004), who showed in crystallographic studies the existence of dimeric and tetrameric forms of ACO from Petunia hybrida. An additional effect on the enzyme kinetics, both in vivo and in vitro can be the result of the fact that ACO is a bi-substrate enzyme, and additionally, the presence of iron, ascorbate and $\mathrm{CO}_{2}$ are necessary for its activity (Bouzayen et al. 1991; Ververidis \& John 1991; Smith \& John 1993; Yang \& Dong 1993; Mathooko 1996; Mirica \& Klinman 2008).

\section{Time course of in vitro ACC oxidase activity}

The velocity (the rate of ethylene released over time) of the in vitro ACC oxidase activity at $25^{\circ} \mathrm{C}$ reached the maximum value after 30 min (Fig. 4) and until 120 min velocity was maintained at about $2.3 \mathrm{~nL}$ ethylene $\cdot \mathrm{mg}$ protein ${ }^{-1} \cdot \mathrm{h}^{-1}$. Even after five hours, the velocity of the enzymatic reaction was maintained $\left(2.1 \mathrm{~nL} \mathrm{C}_{2} \mathrm{H}_{4} \cdot \mathrm{mg}_{\text {protein }}{ }^{-1} \cdot \mathrm{h}^{-1}\right)$. The time course of activity shows linearity in ACC $\left(10^{-3} \mathrm{M}\right)$ conversion into ethylene in the crude extract at $25{ }^{\circ} \mathrm{C}$ for at least five hours (Fig. 4). However, nonlinear time-course for in vitro ACO was previously reported in some cases - for partially purified enzyme from melon fruits (Smith et al. 1992), for tomato ACO purified from transformed Escherichia coli (Smith \& John 1993) and for crude extract from carnation petals (Nijenhuis-de Vries et al. 1994).

\section{In vivo and in vitro ACC oxidase activity in time- course of germination}

Figure 5 shows the activity of the ACC oxidase during seed germination. Conversion of ACC into ethylene in vivo was detectable after 24 hours of germination, i.e., after radicle protrusion through testa and pericarp. Neither in vivo nor in vitro activity was detectable in dry seeds. In vitro ACC oxidase activity was detectable in the crude extracts from whole achenes after 12 hours of seed germination (Fig. 5).

Whole achenes of $C$. chinensis do not produce detectable amounts of ethylene during the first hours of imbibition, similar to sunflower achenes (Corbineau et al. 1989; Chojnowski et al. 1997). Ethylene evolution in vivo, even in the presence of $10^{-3} \mathrm{M}$ ACC was observed when majority of seeds in the sample had already germinated, i.e., after 24 hours of imbibition (Fig. 5). 
It is possible, similar to the sunflower seeds, that pericarp is the main barrier for ethylene release or can inhibit ACC conversion to ethylene, because it may be rich in phenolic compounds (Corbineau et al. 1989). However, if assayed in vitro, $C$. chinensis seeds did not show significant differences in ACO activity with or without pericarp (data not shown). Non-dormant seeds of sunflower, even after the removal of the pericarp, were not able to convert ACC to ethylene during the first four hours of imbibition (Corbineau et al. 1989; Chojnowski et al. 1997). Afterwards, seeds could convert ACC to ethylene and produce endogenous ethylene. The level of this production was increasing during the progress of germination and in many seeds was correlated with seed vigor (Fu et al. 1988; Gorecki et al. 1991; Khan 1994; Chojnowski et al. 1997, Siriwitayavan et al. 2003). Even though in vitro ACO activity in germinating seeds of $C$. chinensis was detectable earlier than in vivo (Fig. 5), there was no ACO activity in dry seeds. Both in vivo and in vitro ACO activity increased with progress in the germination process, contrary, for example, to the ACO from A. caudatus seeds assayed in vitro, which already increased after the germination was completed (Kępczyński et al. 1999).

Even if there is no radicle protrusion during germination in the water, germination sensu stricto (as defined by Côme \& Thévenot 1982) takes place. In $C$. chinensis, similar to sunflower seeds, the ability to convert ACC to ethylene increases with increased imbibition time (Chojnowski et al. 1997). In sunflower seeds this effect can be maintained during storage of primed seeds (Chojnowski et al. 1997). Thus, the activity of ACO in C. chinensis seeds is associated with germination sensu stricto, and seems to be a good marker of this process, which takes place, for example, during seed osmoconditioning.

Table 2. Apparent $\mathrm{V}_{\max }, \mathrm{K}_{\mathrm{m}}$ and Hill coefficient $h$ of ACC oxidase from Callistephus chinensis seeds analyzed in vivo and in vitro at $25^{\circ} \mathrm{C}$

\begin{tabular}{cccc}
\hline ACC oxidase activity & $\mathbf{V}_{\max }\left(\mathbf{n L} \mathbf{C}_{2} \mathbf{H}_{\mathbf{4}} \cdot \mathbf{m g}\right.$ protein $\left.^{\mathbf{- 1}} \cdot \mathbf{h}^{-\mathbf{1}}\right) \pm \mathbf{S E}$ & $\mathbf{K}_{\mathbf{m}}$ for $\mathbf{A C C}(\boldsymbol{\mu M}) \pm \mathbf{S E}$ & Hill coefficient $\boldsymbol{h} \pm \mathbf{S E}$ \\
\hline In vivo & $10.89 \pm 1.13$ & $368 \pm 92$ & $0.63 \pm 0.097$ \\
\hline In vitro & $2.299 \pm 0.14$ & $154 \pm 20$ & $1.73 \pm 0.39$ \\
\hline
\end{tabular}

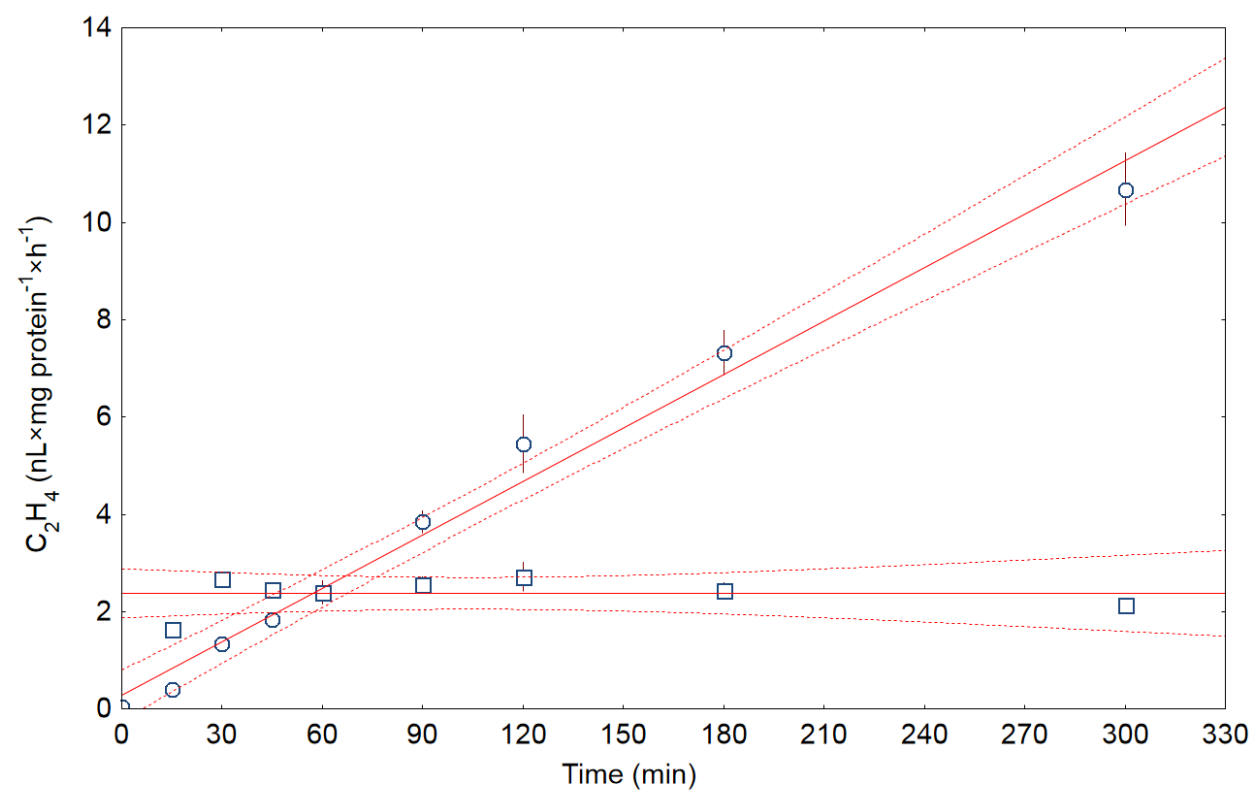

Figure 4. Time-course (total ethylene accumulation) ( $\circ$ ) and velocity (amount of ethylene formed per hour) ( $\square$ ) of activity in vitro ACC oxidase from Callistephus chinensis seeds germinated for $48 \mathrm{~h}$; vertical bars denote $\pm \mathrm{SE}$; dashed lines are $95 \%$ confidence intervals for linear data fitting 


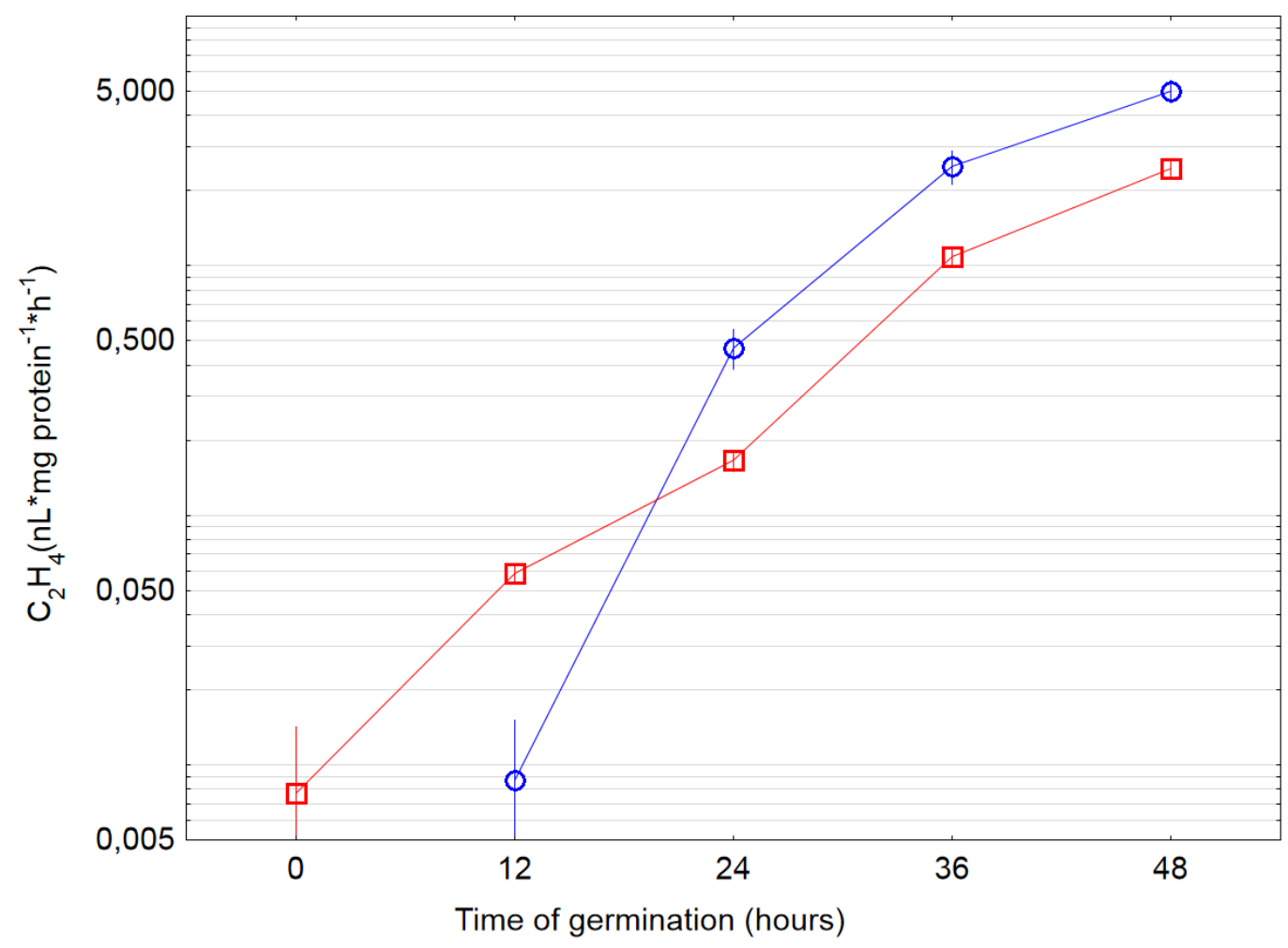

Figure 5. In vivo (०) and in vitro ( $\square$ ) ACC oxidase activity in seeds germinated for different period. Ethylene production shown in log-decimal scale; vertical bars denote \pm SE

\section{CONCLUSIONS}

The data obtained suggest that ACO in Callistephus chinensis seeds has relatively low affinity for the substrate. The results of our experiment suggest that ACO from $C$. chinensis seeds is an oligomeric enzyme with at least two substrate binding sites.

The activity of ACO in $C$. chinensis seeds is detectable in vitro after $12 \mathrm{~h}$ of germination and in vivo after $24 \mathrm{~h}$ of germination. Testing seed vigor by measuring ACO activity is relatively fast and easy by using gas chromatography. However, surrounding tissues - testa and/or pericarp are barriers for early detection of its activity in vivo.

High correlation of endogenous ethylene production and ACC conversion into ethylene with seed germination, particularly with their vigor, which is correlated with both advancement in germination sensu stricto and seed ageing, enable precise control of seed quality during storage. The method can be particularly useful in testing the vigor of the seeds stored in gene banks, where regular monitoring of the germplasm quality is necessary.

\section{REFERENCES}

Bailly C., Bogatek R., Dumet D., Corbineau F., Côme D. 1995. Effects of 1-aminocyclopropane-1-carboxylic acid and oxygen concentrations on in vivo and in vitro activity of ACC oxidase of sunflower hypocotyl segments. Plant Growth Regulation 17: 133-139. DOI: 10.1007/bf00024173.

Barros R.S., Pinheiro F.J.A., Müller C., Pires M.V., da Silva A.G.V., Ribeiro D.M. 2013. Detection of 1aminocyclopropane-1-carboxylate oxidase activity in seeds of Stylosanthes humilis H.B.K. Theoretical and Experimental Plant Physiology 25(3): 231-239. DOI: 10.1590/s2197-00252013000300008.

Bouzayen M., Felix G., Latché A., Pech J.-C., Boller T. 1991. Iron: an essential cofactor for the conversion of 1-aminocyclopropane-1-carboxylic acid to ethylene. Planta 184: 244-247. DOI: 10.1007/bf00197953.

Bradford M.M. 1976. A rapid and sensitive method for the quantitation of microgram quantities of protein utilizing the principle of protein-dye binding. Analytical Biochemistry 72: 248-254. DOI: 10.1016/0003-2697(76)90527-3. 
Chojnowski M. 2000. Effect of temperature on China aster (Callistephus chinensis) seed germination. Zeszyty Naukowe Instytutu Sadownictwa i Kwiaciarstwa 7: 317-321. [in Polish with English abstract]

Chojnowski M., Corbineau F., Côme D. 1997. Physiological and biochemical changes induced in sunflower seeds by osmopriming and subsequent drying, storage and aging. Seed Science Research 7: 323-331. DOI: 10.1017/s096025850000372x.

Corbineau F., Rudnicki R.M., Côme D. 1989. ACC conversion to ethylene by sunflower seeds in relation to maturation, germination and thermodormancy. Plant Growth Regulation 8: 105-115. DOI: 10.1007/bf00024769.

Corbineau F., Xia Q., Bailly C., El-Maarouf-Bouteau H. 2014. Ethylene, a key factor in the regulation of seed dormancy. Frontiers in Plant Science 5; 539; 15 p. DOI: $10.3389 /$ fpls.2014.00539.

Côme D., Thévenot C. 1982. Environmental control of embryo dormancy and germination. In: Khan A.A. (Ed.), The physiology and biochemistry of seed development, dormancy and germination. Elsevier Biomedical, Amsterdam, pp. 271-298.

Copeland R.A. 2000. Cooperativity in enzyme catalysis. Enzymes. A Practical Introduction to Structure, Mechanism, and Data Analysis. Wiley-VCH, pp. 367-384.

Dell 2016. Dell Statistica (data analysis software system), version 13. software.dell.com

Fernández-Maculet J.C., Yang S.F. 1992. Extraction and partial characterization of the ethylene-forming enzyme from apple fruit. Plant Physiology 99: 751754. DOI: 10.1104/pp.99.2.751.

Finlayson S.A., Reid D.M., Morgan P.W. 1997. Root and leaf specific ACC oxidase activity in corn and sunflower seedlings. Phytochemistry 45: 869-877. DOI: 10.1016/s0031-9422(97)00080-0.

Fu J.R., Lu X.H., Chen R.Z., Zhang B.Z., Liu Z.S., Li Z.S., Cai D.Y. 1988. Osmoconditioning of peanut (Arachis hypogea L.) seeds with PEG to improve vigour and some biochemical activities. Seed Science and Technology 16: 197-212.

Gong D., McManus M.T. 2000 Purification and characterisation of two ACC oxidases expressed differentially during leaf ontogeny in white clover. Physiologia Plantarum 110: 13-21. DOI: 10.1034/j.1399-3054.2000.110102.x.
Gorecki R.J., Ashino H., Satoh S., Esashi Y. 1991. Ethylene production in pea and cocklebur seeds of differing vigour. Journal of Experimental Botany 42: 407-414. DOI: 10.1093/jxb/42.3.407.

Grzesik M., Górnik K., Chojnowski M.G. 1997. Maternal effects on Callistephus chinensis seed yield and quality. Basic and applied aspects of seed biology. Current Plant Science and Biotechnology in Agriculture 30: 129-135. DOI: 10.1007/978-94-011-5716-2_15.

Houben M., Van de Poel B. 2019. 1-aminocyclopropane1-carboxylic acid oxidase (ACO): The enzyme that makes the plant hormone ethylene. Frontiers in Plant Science 10: 695. DOI: 10.3389/fpls.2019.00695.

Kępczyński J., Kępczyńska E. 1997. Ethylene in seed dormancy and germination. Physiologia Plantarum 101: 720-726. DOI: 10.1111/j.13993054.1997.tb01056.x.

Kępczyński J., Białecka B., Kępczyńska E. 1999. Ethylene biosynthesis in Amaranthus caudatus seeds in response to methyl jasmonate. Plant Growth Regulation 28: 59-65. DOI: 10.1023/a:1006201625637.

Khan A.A. 1994. ACC-derived ethylene production, a sensitive test for seed vigor. Journal of the American Society for Horticultural Science 119: 10831090. DOI: 10.21273/jashs.119.5.1083.

Kuai J., Dilley D.R. 1992. Extraction, partial purification and characterization of 1-aminocyclopropane-1carboxylic acid oxidase from apple fruit. Postharvest Biology and Technology 1: 203-211. DOI: 10.1016/0925-5214(92)90003-8.

Matilla A.J. 2000. Ethylene in seed formation and germination. Seed Science Research 10: 111-126. DOI: 10.1017/s096025850000012x.

Mathooko F.M. 1996. Regulation of ethylene biosynthesis in higher plants by carbon dioxide. Postharvest Biology and Technology 7: 1-26. DOI: 10.1016/0925-5214(95)00026-7.

McGarvey D.J., Christoffersen R.E. 1992. Characterization and kinetic parameters of ethylene-forming enzyme from avocado fruit. Journal of Biological Chemistry 267: 5964-5967.

Mirica L.M., Klinman J.P. 2008. The nature of $\mathrm{O}_{2}$ activation by the ethylene-forming enzyme 1-aminocyclopropane-1-carboxylic acid oxidase. Proceedings of the National Academy of Sciences 105(6): 1814-1819. DOI: 10.1073/pnas.0711626105. 
Muñoz de Rueda P., Gallardo M.G., Matilla A.J., Sánchez-Calle I.M. 1995. Preliminary characterization of 1-aminocyclopropane-1-carboxylate oxidase properties from embryonic axes of chick-pea (Cicer arietinum L.) seeds. Journal of Experimental Botany 46: 695-700. DOI: 10.1093/jxb/46.6.695.

Nijenhuis-de Vries M., Woltering E.J., de Vrije T. 1994. Partial characterization of carnation petal 1-aminocyclopropane-1-carboxylate oxidase. Journal of Plant Physiology 144: 549-554. DOI: 10.1016/s0176-1617(11)82136-X.

Pech J.C., Latché A., Bouzayen M. 2010. Ethylene biosynthesis. In: Davies P.J. (Ed.), Plant hormones, 3rd ed. Springer, Dordrecht, pp. 115-136. DOI: 10.1007/978-1-4020-2686-7_6.

Petruzzelli L., Coraggio I., Leubner-Metzger G. 2000. Ethylene promotes ethylene biosynthesis during pea seed germination by positive feedback regulation of 1-aminocyclo-propane-1-carboxylic acid oxidase. Planta 211: 144-149. DOI: 10.1007/s004250000274.

Reynolds E.A., John P. 2000. ACC oxidase is found in seedlings of two (Coniferales, Gnetales) of the four gymnosperm orders. Physiologia Plantarum 110: 38-41. DOI: 10.1034/j.1399-3054.2000.110105.x.

Ruduś I., Sasiak M., Kępczyński J. 2013. Regulation of ethylene biosynthesis at the level of 1-aminocyclopropane-1-carboxylate oxidase (ACO) gene. Acta Physiologiae Plantarum 35: 295-307. DOI: 10.1007/s11738-012-1096-6.

Samimy C., Taylor A.G. 1983. Influence of seed quality on ethylene production of germinating snap bean seeds. Journal of the American Society for Horticultural Science 108: 767-769.
Siriwitayawan G.A., Downie B., Geneve R.L. 2003. Ethylene evolution is positively correlated with seed vigor in sweet corn and tomato seed lots with differing vigor levels but similar germination capacity. Journal of the American Society for Horticultural Science 128(4): 608-614. DOI: 10.21273/jashs.128.4.0608.

Smith J.J., John P. 1993. Activation of 1-aminocyclopropane-1-carboxylate oxidase by bicarbonate/carbon dioxide. Phytochemistry 32: 1381-1386. DOI: 10.1016/0031-9422(93)85142-e

Smith J.J., Ververidis P., John P. 1992. Characterization of the ethylene-forming enzyme partially purified from melon. Phytochemistry 31: 1485-1494. DOI: 10.1016/0031-9422(92)83092-d.

Ververidis P., John P. 1991. Complete recovery in vitro of ethylene-forming enzyme activity. Phytochemistry 30: 725-727. DOI: 10.1016/0031-9422(91)85241-q.

Wawrzyńczak A. 2002. Wpływ inhibitorów biosyntezy i działania etylenu oraz regulatorów wzrostu na niektóre procesy metaboliczne i trwałość goździków (Dianthus caryophyllus L.). PhD thesis, Research Institute of Pomology and Floriculture, Skierniewice, Poland. [in Polish]

Yang S.F., Dong J.G. 1993. Recent progress in research of ethylene biosynthesis. Botanical Bulletin of Academia Sinica 34(2): 89-101.

Zhang Z., Ren J-Z., Clifton I.J., Schofield C.J. 2004. Crystal structure and mechanistic implications of 1-aminocyclopropane-1-carboxylic acid oxidase - the ethylene-forming enzyme. Chemistry and Biology 11: 1383-1394. DOI: 10.1016/j.chembiol.2004.08.012. 